\title{
Kualitas Pelayanan Rawat Inap Di Rsu Muhammadiyah Ponorogo
}

\section{Inpatient Service Quality in the Muhammadiyah Ponorogo Hospital}

\author{
Yelli Arista Rachmawati, Sudarmo, Drajat Tri Kartono \\ Magister Administrasi Publik, Universitas Sebelas Maret Surakarta \\ yellijelly@gmail.com
}

\begin{abstract}
Abstrak
Kualitas merupakan salah satu komponen penting di dalam pelayanan publik, khususnya pelayanan kesehatan. Rumah sakit sebagai salah satu dari penyedia layanan kesehatan masyarakat harus mampu menjalankan fungsi dan wewenngnya dengan baik demi terciptanya pelayanan kesehatan dengan kualitas pelayanan yang baik. Dari penelitian yang dilakukan kualtias pelayanan terutama pelayanan rawat inap di RSU Muhammadiyah sudah baik, meskipun masih perlu ditingkatkan kembali demi terciptanya pelayanan yang lebih baik di masa yang akan datang.
\end{abstract}

\section{Kata Kunci : Kualitas Pelayanan, Pelayanan Kesehatan, Rumah Sakit}

\begin{abstract}
Quality is one of the important component in public services, especially health service. Hospital is one of health service provider. Hospital as a helath service provider should be able to run the function and the authority well in order to create the helath service with the good service quality. The result of research about the quality of helath service at the RSU Muhammadiyah Ponorogo especially about inpatient service is good, although its still needs to be increased in order to create the better quality service in the future.
\end{abstract}

\section{Keywords : Quality Service, Health Service, Hospital}

\section{A. Pendahuluan}

Rumah sakit merupakan unit pelayanan publik di bidang kesehatan. Dalam hal ini merupakan unit yang melayani rawat inap harus mampu menjalankan fungsi dan wewenangnya dengan baik demi terciptanya pelayanan kesehatan dengan kualitas pelayanan yang baik. Semakin meningkatnya tuntutan masyarakat akan mutu pelayanan maka fungsi pelayanan kesehatan termasuk pelayanan dalam rumah sakit secara bertahap perlu terus ditingkatkan agar menjadi lebih efektif dan efisien serta memberi kepuasan terhadap pasien, keluarga maupun masyarakat.
Pelayanan yang bermutu haruslah berorientasi pada tercapainya kepuasan pelanggan agar dapat tetap eksis di tengah persaingan global.

Penyelenggaraan pelayanan kesehatan yang semakin kompleks menuntut kapasitas pengelolaan yang kuat. Sistem pelayanan kesehatan yang padat teknologi dan semakin mahal menuntut penanganan yang professional dan menuntut metoda penyelenggaraan yang mampu bekerja efektif, efisien dan sekaligus memuaskan. Apabila tidak adanya sikap professional dari petugas itu sendiri dalam 
melaksanakan tanggungjawabnya maka akan mempengaruhi proses pelayanan kesehatan.

Petugas rumah sakit terkadang menganggap dirinya jauh di atas pasien, merasa sangat dibutuhkan pasien dan merasa paling tahu tentang cara-cara menyembuhkan pasien. Pemikiran seperti itulah yang pada akhirnya berdampak pada sikap yang seenaknya dalam memberikan pelayanan kepada pasien. Pelayanan yang cepat, tepat, dan sikap ramah dari para petugas adalah yang diharapkan pasien ketika berkunjung di rumah sakit. Karena posisi keadaan mereka adalah sakit, yang lebih banyak membutuhkan perlakuan yang nyaman.

Oleh karena itu, mengingat pentingnya tercapainya akuntabilitas dan penerapan sepenuhnya dalam pelayanan kesehatan masyarakat maka timbul ketertarikan penulis untuk mengadakan penelitian untuk mengetahui apakah pelayanan kesehatan di RSU Muhammadiyah Ponorogo khususnya pelayanan rawat inap sudah dilakukan dengan baik.

Teori mengenai kualitas pelayanan yang pertama diungkapkan menurut Kotler (2002 : 83) definisi pelayanan adalah setiap tindakan atau kegiatan yang dapat ditawarkan oleh satu pihak ke pihak lain, yang pada dasarnya tidak berwujud dan tidak mengakibatkan kepemilikanapapun. Produksinya dapat dikaitkan atau tidak dikaitkan pada satu produk fisik.Pelayanan merupakan perilaku produsen dalam rangka memenuhi kebutuhan dan keinginan konsumen demi tercapainya kepuasan pada konsumen itu sendiri. Kotler juga mengatakan bahwa perilaku tersebut dapat terjadi pada saat, sebelum dan sesudah terjadinya transaksi. Pada umumnya pelayanan yang bertaraf tinggi dapat menghasilkan kepuasan yang tinggi serta pembelian ulang yang lebih sering. Kata kualitas mengandung banyak definisi dan makna, orang yang berbeda akan mengatakannya secara berlainan, tetapi dari beberapa definisi yang dapat kita jumpai memiliki beberapa kesamaan walaupun hanya cara penyampaiannya saja biasanya terdapat pada elemen sebagai berikut : (1) Kualitas meliputi usaha dalam memenuhi atau melebihkan harapan pelanggan; (2) Kualitas mencakup produk, jasa, manusia, proses dan lingkungan; (3) Kualitas merupakan kondisi yang selalu berubah.

Kualitas pelayanan adalah segala bentuk aktivitas yang dilakukan oleh perusahaan guna memenuhi harapan konsumen. Pelayanan dalam hal ini diartikan sebagai jasa atau service yang disampaikan oleh pemilik jasa yang berupa kemudahan, kecepatan, hubungan, kemampuan dan keramah-tamahan yang ditujukan melalui sikap dan sifat dalam memberikan pelayanan untuk kepuasan konsumen. Kualitas pelayanan dapat diketahui dengan cara membandingkan persepsi para konsumen atas pelayanan yang nyatanyata mereka terima dengan pelayanan yang sesungguhnya mereka inginkan terhadap atribut-atribut pelayanan suatu instansi pemerintah maupun perusahaan. Instansi atau perusahaan menganggap konsumen sebagai raja yang harus dilayani dengan baik, mengingat konsumen sebagai pemberi keuntungan kepada instansi atau perusahaan agar dapat terus hidup. 
Kualitas pelayanan telah terbukti menjadi konsep yang sulit untuk dipahami (Brady \& Cronin, 2001), karena layanan telah digambarkan sebagai perwujudan yang heterogen dan tidak terpisahkan (Parasuraman et al, 1985, Zhao et al, 2002). Hal ini disebut sebagai 'sulit dipahami' (Parasuraman et al, 1985, Smith, 1999)., 'terselesaikan' (Caruana et al, 2000, hal 57)., dan 'jauh dari meyakinkan' (Athanassopoulos, 2000, hal 191).Meskipun ada konsensus tentang bagaimana untuk mengukur kualitas layanan, tidak ada konsensus tentang apa yang harus diukur. Dalam literature ada 2 konseptualisasiutama kualitas pelayanan. Salah satunya adalah perspektif "Nordic (Gro, 'nroos, 1982, 1984, 1990) yang mendefinisikan dimensi kualitas pelayanan secara global yang terdiri dari proses dan kualitas hasil (Brady \& Cronin, 2001). Kualitas proses mengacu pada kualitas proses pelayanan atau bagaimana layanan ini disampaikankepadapelanggan.kualitas hasil mengacu pada kualitas hasil layanan, atau apa yang pelanggan terima sebagai hasil dari transaksi layanan."

Selanjutnya mengenai dimensi kualitas pelayanan terlepas dari pemberian layanan, pada dasarnya konsumen menggunakan kriteria yang sama dalam mengevaluasi kualitas pelayanan. Kriteria tersebut masuk dalam 10 kategori utama. Pandangan kualitas pelayanan konsumen dijelaskan lebih lanjut dalam (1) Reliability menyangkut konsistensi dari performance dan dapat dipercaya; (2) Responsiveness dalam menyangkut kemauan atau kesiapan karyawan untuk memberikan pelayanan. Hal ini juga menyangkut ketepatan waktu dari pelayanan; (3) Competence yang bermakna memiliki keahlian dan pengetahuan yang dibutuhkan untuk memberikan pelayanan; (4) Access menyangkut kemudahan untuk dihubungi; (5) Courtesy menyangkut etika kesopanan, rasa hormat, kesungguhan, keramahtamahan dari penyedia jasa; (6) Communication berarti menjaga agar setiap pelanggan mendapat informasi sesuai dengan bahasa yang mereka pahami dan mendengarkan keinginan mereka. Hal ini berarti perusahaan jasa transportasi tersebut harus menyesuaikan bahasa mereka dengan konsumen yang berbeda, meningkatkan level bahasa pada pelanggan yang berpendidikan baik serta berbicara secara mudah dan sederhana kepada orang yang baru; (7) Credibility menyangkut dapat dipercaya, kejujuran penyedia jasa. Hal ini bermakna konsumen memiliki ketertarikan di hati; (8) Security adalah bebas dari bahaya, resiko, maupun keraguan; (9) Understanding/knowing the customer menyangkut berusaha untuk memahami apa yang konsumen butuhkan; (10) Tangibles menyangkut lingkungan fisik dan gambaran fisik dari suatu jasa.

Dimensi-dimensi kualitas pelayanan di atas kemudian dibentuk ulang oleh Zeithmal dan Bitner (2006 : 116-119) mengemukakan 5 dimensi dalam menentukan kualitas pelayanan, yaitu : (1) Reability, yaitu kemampuan untuk memberikan pelayanan yang sesuai dengan janji yang ditawarkan; (2) Responsiveness, yaitu respon atau kesigapan karyawan dalam membantu pelanggan dan memberikan pelayanan yang cepat dan tanggap; (3) Assurance, meliputi kemampuan karyawan atas pengetahuan terhadap produk secara tepat, kualitas keramah-tamahan, perhatian dan kesopanan dalam memberikan pelayanan, 
dan kemampuan dalam menanamkan kepercayaan pelanggan terhadap perusahaan. Dimensi kepastian atau jaminan ini merupakan gabungan dari dimensi : Competence, Courtesy, Credibility; (4) Empathy, yaitu perhatian secara individual yang diberikan perusahaan kepada pelanggan seperti kemudahan untuk menghubungi perusahaan, kemampuan karyawan untuk berkomunikasi dengan pelanggan, dan usaha perusahaan untuk memahami keinginan dan kebutuhan pelanggannya. Dimensi empati ini merupakan penggabungan dari dimensi : Access dan Communication; (5) Tangibles, meliputi penampilan fisik seperti gedung dan ruangan front office, tersedianya tempat parker, kebersihan, kerapihan dan kenyamanan ruangan, kelengkapan peralatan komunikasi dan penampilan karyawan.

\section{B. Metode Penelitian}

Penelitian ini menggunakan metode penelitian deskriptif kualitatif, dengan pengambilan sampel penelitian di RSU Muhammadiayah Ponorogo. Pengumpulan data menggunakan teknik wawancara, observasi, dan dokumentasi. Informan diperoleh dari pasien dan atau keluarga pasien yang pernah atau sedang menjalani rawat inap di RSU Muhammadiyah. Data yang dipeoleh kemudian dianalisis dengan cara meninjau kembali hasil dari wawancara, observasi, dan dokumentasi yang telah dilakukan. Kualitas pelayanan di RSU Muhammadiyah diukur berdasarkan teori yang dikemukakan oleh Zeithmal dan Bitner (2006 : 116-119) yaitu menggunakan 5 dimensi kualitas pelayanan, antara lain: reability, responsiveness, assurance, empathy, dan tangibles.

\section{Hasil dan Pembahasan}

\section{Reability}

Kemampuan petugas dalam memberikan pelayanan kesehatan yaitu baik. Mulai dari pelayanan yang dilakukan pada saat mendaftar, pelayanan dokter, pelayanan yang dilakukan oleh unit keperawatan, pelayanan oleh unit gizi, kenyamanan dan keamanan selama melakukan perawatan inap, serta pelayanan yang dilakukan di unit farmasi. Semua unit mampu untuk melakukan tindakan sesuai dengan peraturan yang berlaku.

\section{Responsiveness}

Respon atau kesigapan karyawan dalam membantu pelanggan dan memberikan pelayanan yang cepat dan tanggap, yang dapat dilihat dari tanggapnya unit keperawatan, unit dokter dalam menangani pasien ketika dalam keadaan darurat, cepat dan tanggapnya unit farmasi dalam mengerjakan resep sesuai dengan peraturan, dapat disimpulkan bahwa responsiveness di RSU Muhammadiyah Ponorogo baik.

\section{Assurance}

Dimensi ketiga ini meliputi kemampuan karyawan atas pengetahuan terhadap produk secara tepat, kualitas keramahtamahan, perhatian dan kesopanan dalam memberikan pelayanan, dan kemampuan dalam menanamkan kepercayaan pelanggan terhadap perusahaan. Berdasarkan hasil kuisioner yang diisi oleh pasien dan atau keluarga pasien yang melakukan rawat inap, keramahan, perhatian dan kesopanan petugas mulai 
dari unit pendaftaran sampai unit farmasi adalah baik.

\section{Empathy}

Dimensi yang keempat ini dapat dilihat dari perhatian secara individual yang diberikan perusahaan kepada pelanggan seperti kemudahan untuk menghubungi perusahaan, kemampuan karyawan untuk berkomunikasi dengan pelanggan, dan usaha perusahaan untuk memahami keinginan dan kebutuhan pelanggannya. Pelayanan yang dilakukan di RSU Muhammadiyah Ponorogo sudah baik dari segi kemudahan untuk menghubungi kontak petugas, kemampuan karyawan dalam berkomunikasi dengan pasien, serta RSU Muhammadiyah sudah berusaha memahami keinginan dan kebutuhan pasien yang melakukan rawat inap di tempat tersebut.

\section{Tangibles}

Dimensi kualitas pelayanan yang terakhir adalah tangibles, yang meliputi penampilan fisik seperti gedung dan ruangan front office, tersedianya tempat parkir, kebersihan, kerapihan dan kenyamanan ruangan, kelengkapan peralatan komunikasi dan penampilan karyawan. Sarana dan prasarana yang ada di RSU Muhammadiyah Ponorogo sudah lengkap. Sarana yang ada di RSU Muhammadiyah berupa alat-alat medis baik yang ada di ruang perawatan maupun alat-alat yang ada di ruang laboratorium ataupun di ruang Radiologi. Alat-alat medis yang ada di rumah sakit sudah lumayan lengkap. Alat-alat di laboratorium sudah lengkap, alat-alat di Instalasi Radiologi juga sudah lumayan lengkap kecuali alat scan. Sehingga apabila ada pasien yang membutuhkan proses scan harus dirujuk ke instansi lain. Kemudian terdapat juga 2 (dua) unit ambulance dan 1 (satu) unit mobil jenazah yang siap melayani 24 jam.

Prasarana yang ada di RSU Muhammadiyah meliputi ruang-ruang pelayanan mulai dari IGD, Instalasi Farmasi dan ruang Logistik Farmasi, Ruang Laboratorium, Ruang Instalasi Radiologi, ruang-ruang perawatan inap, ruang poliklinik, Instalasi Bedah Sentral dan ruang pemulihan pasca operasi, Ruang ICU/ICCU, Instalasi Gizi, Ruang Loundry, Ruang Security, ruangan Administrasi, Ruang Teknisi, dan lain-lain. Prasarana yang tersedia di RSU Muhammadiyah sudah cukup memenuhi kebutuhan masyarakat dalam hal kesehatan. Tetapi ada beberapa kendala terkait ruang tunggu poliklinik yang tidak cukup menampung pasien dan keluarganya pada saat melakukan kontrol setelah rawat inap.

\section{Penutup}

Berdasarkan hasil penelitian yang dilakukan, maka dapat disimpulkan bahwa kualitas pelayanan terutama kualitas pelayanan rawat inap sudah baik. Namun ada beberapa aspek yang masih perlu ditingkatkan lagi demi terwujudnya pelayanan yang lebih baik dikemudian hari.

\section{Daftar Pustaka}

Himawan, Febtiono. (2016). Kinerja Pegawai Dalam Pelayanan Kesehatan Masyarakat di Puskesmas Sempaja Kota Samarinda. Skripsi.

Moleong, Lexy.(2002). Metodologi Penelitian Kualitatif. Bandung. PT. remaja Rosdakarya. 
Starling, G. (2008). Managing the Public Sector (8th ed.). Boston, MA: Thomson Higher Education.

Sholeh, Chabib dkk, (2010), Pengelolaan Keuangan dan Aset Daerah Sebuah Pendekatan Struktural Menuju Tata Kelola Pemerintahan Yang Baik. Bandung: Fokusmedia.

Ratminto, dkk. (2005). ManajemenPelayanan.

Yogyakarta: Pustaka Pelajar.

Kotler, Philip, (2002), Manajemen Pemasaran, Jilid 1, Edisi Milenium, Jakarta, Prehallindo.

Zeithaml.Valarie, dkk. (2006). Service Marketing - Integrating Customer Focus Accross The Firm Forth Edition. New York: McGraw Hill. Sugiyono. (2012). Metode Penelitian Kuantitatif, Kualitatif dan $R \& D$. Bandung: Alfabeta.

Nasution, 1988. Matode Penelitian Naturalistik Kualitatif. Bandung: Tarsito 